\title{
Erken Olgunlaşma Dönemindeki Geleneksel Peynir Mikrobiyomunun Metagenomik Analizi
}

\author{
Sadık Savaşan, Devrim Beyaz \\ Aydın Adnan Menderes Üniversitesi Veteriner Fakültesi, Besin Hij. ve Tek. AD, Aydın
}

Geliş Tarihi / Received: 23.01.2019, Kabul Tarihi / Accepted: 30.04.2019

\begin{abstract}
Özet: Bu araştırmada, dağ köylerinde çiğ koyun sütünden üretilen geleneksel peynirlerin erken olgunlaşma döneminde alınan örneklerinin yeni nesil sekanslama ve metagenomik analiz ile mikrobiyotaları saptanmıştır. Firmicutes ortalama $\% 91,5$ ile en yoğun filum olarak bulunurken, Actinobacteria en seyrek filum olarak $(\% 0,01)$ bulundu. Peynir örneklerinin metagenomik analizi sonucunda 25 cins belirlenirken bunlardan 23'ü tüm örneklerde ortak olarak bulundu. Cins düzeyinde en yüksek çeşitlilik 13 cins ile Enterobacteriaceae familyası içinde görüldü. Tüm örneklerde en baskın tür Lactococcuc lactis (ort.\%84) olarak belirlendi. Tüm türler referans genlere \%99'un üzerinde homoloji gösterdi.
\end{abstract}

Anahtar kelimeler: Peynir, mikrobiyom, mikrobiyota, metagenomik analiz, Lactococcus lactis

\section{Metagenomic Analysis of the Early Ripened Continental Cheese Microbiome}

\begin{abstract}
In this study, microbiota of early ripened continental cheeses from raw sheep milk collected from mountain villages was determined by next-generation sequencing and metagenomic analysis. Firmicutes was found as the dominant phylum by the avearge of $91,5 \%$, when Actinobacteria was found as the minor phylum $(0,01 \%)$. By the metagenomic analysis of cheese samples 25 genuses were determined, 23 of these genuses were found in all of the cheese samples. In the genus averages, the highest diversity was viewed in Enterobacteriaceae family as 13 genus. Lactococcuc lactis was determined as dominant (avr.84\%) species in all samples. The all species showed more than $99 \%$ homology to the referance genes.
\end{abstract}

Key words: Cheese, microbiome, microbiota, metagenomic analysis, Lactococcus lactis.

\section{Giriş}

Peynir, hammaddenin uygun bir pıhtılaştırıcı kullanılarak pıhtılaştırılması ve pıhtıdan peyniraltı suyunun ayrilmasıyla ya da sütün permenantının ayrılmasından sonra pihtılaştırılmasıyla elde edilen, farklı sertliklerde ve yağ içeriklerinde, salamura ile ya da kuru tuzlama ile tuzlanarak ya da tuzlanmadan, starter kültür kullanarak ya da kullanmadan, telemesi haşlanarak ya da haşlanmadan, çeşnili ya da çeşnisiz olarak, tekniğine uygun olarak üretilen, olgunlaştırılmadan ya da olgunlaştırıldıktan sonra tüketilen, çeşidine özgü karakteristik özellikler gösteren süt ürünüdür [7]. İlk peynirin Orta Doğu insanları ve Orta Asya göçebe Türkleri tarafından yapıldığ1 düşünülmektedir [2]. Peynirin günlük beslenmemizdeki önemi; kolay sindirilebilme özelliğinin yanı sıra, yapısında üretiminde kullanılan sütteki yağı, çözünmeyen tuzları, koloidal maddelerin tümüne yakın miktarını bulundurması ve süt serumundaki çözünen tuzlar, vitaminler, serum proteinleri ve diğer besin unsurlarının da bir ölçüde yapısına girmesinden kaynaklanır [17].
Geleneksel peynirlerin yapımındaki alışalagelmiş, geleneksel yöntemlerin peynirlerin duyusal özellikleri üzerindeki etkisinde mikrobiyotalarının çeşitliliği ve mikrobiyal aktiviteleri önemli yere sahiptir. Geleneksel peynirlerdeki çeşitlilik, herbir peynir tipine göre süt kaynağından olgunlaşmaya her aşamadaki farklilıklar, geniş bir mikrobiyotaya ve çevresel etkilere bağl1 olarak şekillenen mikroorganizma etkileri sonucu oluşmaktadır [9].

Peynir mikrobiyotasının peynirin organoleptik, fiziko-kimyasal özelliklerinin oluşumunda önemli kilit rolü vardır. Peynirlerin sınıflandırılmasında peynirin sahip olduğu mikrobiyal çeşitlilik veya aktivite dikkate alınmamakta, tekstürü, olgunlaşma süresi ve benzeri özelliklerine göre sinıfland1rılmaktadır. Peynir, metabolik olarak aktif bakterileri, maya ve küfleri gibi çeşitlilikleri yapısında barındıran mikrobiyolojik olarak aktif bir gidadır. Moleküler teknikler gida örneklerindeki mikroorganizmaların genetik yapısının analizinde kullanılmaktayken, günümüzde through culture-independent metotlar peynir ve diğer gidaların kompleks 
ekosistemlerinin analiz edilerek anlaşılabilmesini kolaylaştırmıştır [10].

Kültürden bağımsız teknikler, gıda mikrobiyolojisinde önemli yere sahip gıda sistemlerinin mikrobiyotalarının ve mikrobiyal çeşitliliklerinin detaylı araştırılmasını etkin hale getiren yöntemlerdir. Bunlara DNA bazlı tekniklerden, denaturing gradient gel electrophoresis (DGGE), temporal temperature gradient gel electrophoresis (TTGE), single stranded conformation poly-morphisms (SSCP), polymerase chain reaction (PCR) örnek olarak sayılabilirler. Tüm bu teknikler süt ve süt ürünlerinin mikrobiyolojisinin anlaşılmasında önemlidir, ancak mikrobiyal ekoloji alanı da sürekli gelişmektedir. Son yıllarda kültürden bağımsız yöntemlerin yerini next- generation sekans sistemlerinin aldığ 1 görülmektedir. Bu sistemler, pekçok çevresel mikrobiyotanın başarılı șekilde profillerinin saptanmasını sağlamaktadır [11]. High throughput DNA sekans (HTS) tekniği ile oldukça düşük düzeylerdeki bakteriler saptanabilir. HTS yöntemi ile patojenik ve bozulmaya sebep olan bakterilerde saptanabilir. $\mathrm{Bu}$ yöntem kullanılarak peynir yapım aşamalarının her safhasında oluşan ve değişiklikler gösteren mikrobiyota iyi bir şekilde saptanabilir [6]. Son yıllarda geliştirilen yeni nesil DNA dizileme yöntemleri yüksek doğrulukta oldukça hızlı dizileme yapabilen, yoğun ve özgün bilgi sağlayan yöntemlerdir [4]. Yeni nesil DNA dizileme teknolojilerinin ortak özelliği aynı anda milyonlarca kısa dizilemenin yapılabilmesi ve oldukça hızlı şekilde okunabilmesidir. Ayrıca elektroforeze gerek kalmadan gerçek zamanlı okuma yapabilmesi, daha doğru sonuçlar alınabilmesi, daha az hata eğilimli ve daha ekonomik olması bu teknolojilerin eski sisteme göre avantajları arasında yer almaktadır [3,4,14]. Bu araştırmada, dağ köylerinde çiğ koyun sütünden üretilen geleneksel peynirlerin erken olgunlaşma döneminde alınan örneklerinin yeni nesil sekanslama ve metagenomik analiz ile mikrobiyotaları saptanmıştır.

\section{Materyal ve Metod}

\section{Peynir örneklerinin hazırlanması}

Aydın ilinin yüksek rakımlı dağ köylerinde koyun sütünden çiğ olarak üretilen geleneksel peynir örnekleri toplandi. Toplanan 5 adet peynir erken olgunlaşma döneminde incelendi. Peynir kalıbının iç bölgesinden alınan $1 \mathrm{~cm}^{2}$ örnek $25 \mathrm{ml}$ steril DNAfree distile suya eklendi ve stomacher ile homojenize edildi. Bu işlemden sonra bulanık süspansiyon formundaki örnekler TissueLyser (Qiagen) ile muamele edilerek solusyon haline getirildi. 100 mikrolitre örnek moleküler işlemler için ayrıldı. Peynir örneklerinin sekans hazırlığı için, DNA ekstraksiyonu QIAmp DNA Stool Kit (Qiagen) ile üretici firmanın talimatlarına uygun olarak gerçekleştirildi. Mikrobiyal DNA konsantrasyonu Qubit (Thermo) ile ölçüldü ve minumum $1-3 \mathrm{ng}$ arasında olacak şekilde ayarland1.

\section{Yeni Nesil Sekanslama}

16S Metagenomics Kit (Thermo Scientific, USA) ile 2 ayrı PCR mix (1.havuz: 2., 4., 8. varyant bölge; 2.havuz: 3., 6., 7., 9. varyant bölge) hazırland1. Pozitif kontrol olarak 1:20 dilüe edilmiș $(1.5 \mathrm{ng} / \mu \mathrm{l}) \mathrm{E}$. coli DNA kontrol stoğu kullanıldı. PCR analizi sonucu elde edilen ürünler, \%2'lik agaroz jel elektroforezine tabi tutuldu. Jel elektroforezine tabi tutulan PCR ürünleri Agencourt AMPure XP beads (Thermo Scientific, USA) ile DynaMag-2 magneti yard1miyla kitin önerdiği koşullar doğrultusunda pürifiye edildi. Elde edilen DNA'nın kantitasyonu, Ion Universal Library Quantitation Kit (Thermo Scientific, USA) ile üretici firmanın önerdiği koşullara uygun olarak Real-Time PCR analiziyle gerçekleştirildi. DNA konsantrasyonu, dilüsyon/konsantrasyon ayar1 yapılarak gerçekleştirildi.

Ion PGM Hi-Q View OT2 Kit ve Ion PGM Hi-Q View OT2 Solutions (Thermo Scientific, USA) ile firmanın önerdiği koşullar altında emülsiyon PCR'1 gerçekleştirildi. Bu amaçla Ion One Touch 1 (Thermo Scientific, USA) cihazı kullanıld1.

Kütüphane oluşturulması (uçlara tamir enzimi uygulama) için Ion Plus Fragment Library Kit (Thermo Scientific, USA) ile üretici firmanın talimatlarına uygun şekilde kütüphane oluşturuldu. Barkod ligasyonu, adaptör ligasyonu (bir ucu A adaptörü, diğer uca P1 adaptörü) için Barcode Adapters 1-16 Kit (Thermo Scientific, USA) ile kitin önerdiği koşullar doğrultusunda DNA barkod kütüphanesi oluşturuldu.

Mikroçipe yükleme için, PGM analizi için hazırlanan örnekler Ion 318 veya Ion 316 Chip (Thermo Scientific, USA)'e aktarıldı. PGM'de koșturma için, örneklerin yüklendiği mikroçipe Ion torrent (Thermo Scientific, USA) cihazına yerleştirilerek sekans analizi gerçekleştirildi. 


\section{Metagenomik Analiz}

İonReporter programı (Thermo Scientific, USA) tarafindan yapılan bu analizde, okumaların kalite kontrolleri, eşik değerlerde elde edilen data istatistikleri, her bir kompleksin gen içeriğinde değişiklik olup olmadığı, gen bölgesinin konumu ve uzunluğu, gen bölgesi ve her bir gen bazındaki homoloji oranları incelendi. Yeni nesil sekans sisteminin ça1ışması ile ilişskili diğer biyoinformatik analiz sisteme yüklü programlar tarafindan otomatik olarak yapıldı. Bu aşamadaki işlemler özetle, kütüphane oluşturulması ve cihaz çıktılarının dijital ortamda birleştirilerek dizinin oluşturulmasını kapsadı. Son aşama ise, sekanslama sonucunda elde edilen bilgilerin ilk aşamada yapıldığı gibi analizini, ayrıca BLAST programı ile kendi içinde ve GenBankası verileri ile karşılaştırmasını kapsadı. Bu işlemler sonucunda örnekte mevcut tüm prokaryotik organizmaların filumdan türe kadar olan taksonomik düzeylerde orantısal yoğunluğu elde edildi. Ayrıca bu tüm geçerli okumalar OTU (operasyonel taksonomik ünite) olarak alındı. Örneklerdeki familya, cins ve tür düzeyinde alfa-çeşitlilik gösterilmesi için Chao, Shannon ve Simpson rarefaction algoritması kullanıldı. Aşağıda belirtilen okuma kalitesi eşikleri kullanıldı; minimal 10 okuma üstü, minimal 150 baz okuma.

\section{Bulgular}

İncelenen 5 peynir örneğinin yeni nesil DNA sekans1 sonucunda örnek başına ortalama 480653 okuma yapılırken, bunlardan 419842 adeti kalite filtrelerini geçti. Kalite dışı okumalar çıkarıldıktan sonra 330851 adeti haritalandırılarak mevcut bakteri taksonlarından biri ile eşleştirildi. Okuma sayıları kullanılan değişken bölgeye göre farklılık gösterdi. Haritalanan okumalar içinden en yüksek sayıda okuma 188938 ile V3 bölgesinde yapıldı. En düşük sayıda okuma ise 10844 ile V2 bölgesinde yapıldı. İncelenen peynir örneklerinin tümünde 3 'er filum belirlendi. Firmicutes ortalama \%91,5 ile en yoğun filum olarak bulunurken, Actinobacteria en seyrek filum olarak $(\% 0,01)$ bulundu (Tablo1). Sinıf düzeyinde Gammaproteobacteria $(\% 8,4)$ saptanan tek Proteobacteria sınıfı oldu. Tüm peynir örneklerinde Actinobacteria filumu içinde 1, Firmicutes filumu içinde 5, Proteobacteria filumu içinde 3 familya belirlendi. En yüksek oranda bulunan familya $\% 86,2$ ile Streptococcaceae oldu. Bunu Firmicutes filumu içindeki familyalardan Enterococcaceae $(\% 2,7)$ ve Lactobacillaceae $(2,1)$ izledi. Enterobacteriaceae familyası ise $\% 7,6$ oranında bulundu. Genus düzeyinde sonuçlar Tablo2'de gösterilmiştir. Peynir örneklerinin metagenomik analizi sonucunda 25 adet cins belirlendi, bunlardan 23 adeti tüm örneklerde ortak olarak bulundu. Cins düzeyinde en yüksek çeşitlilik 13 cins ile Enterobacteriaceae familyası içinde görüldü. Diğer tüm familyalar en fazla 2 cins ile temsil edildi. Cins düzeyinde en yüksek ortalama relatif yoğunluk gösteren cins Lactococcus $(\% 85,4)$ oldu. Peynir örneklerinin metagenomik analizi ile belirlenen türlerin ortalama relatif \%oranları, pozitif bulunan örnek sayısı ve referans genumlara \% homolojisi Tablo3'de gösterilmiştir. İncelenen örneklerde toplam 59 tür belirlenirken, bunlardan 20 adeti tüm örneklerde ortak olarak bulundu. Toplam 9 Enterococcus türü bulunurken, bunu 6 tür ile $L a$ ctobacillus, 5 tür ile Buttiauxiella ve 4 tür ile $\mathrm{La}$ ctococcus ve Citrobacter takip etti. Lactobacillus lactis tek başına $\% 84$ relatif yoğunluk ile en baskın tür olarak belirlendi. Bundan sonraki en yüksek diğer türler Enterococcus italicus (\%1,8), Citrobacter freundii $(\% 1,7)$, Lactococcus raffinolactis $(\% 1,35)$, Lactobacillus brevis $(\% 1,1)$ olarak saptand. Tüm türler referans genlere \%99'un üzerinde homoloji gösterdi.

Tablo1. Peynir örneklerinin metagenomik analizi ile belirlenen üst taksonlar ortalama relatif \% oranları

\begin{tabular}{lclclclcc}
\hline Filum & \% oranı Sinıf & \% oranı & Takım & \% oranı & Familya & \% oranı \\
\hline Actinobacteria & 0,01 & Actinobacteria & 0,01 & Actinomycetales & 0,01 & Micrococcaceae & 0,01 \\
Firmicutes & 91,58 & Bacilli & 91,58 & Bacillales & 0,24 & Staphylococcaceae & 0,24 \\
& & & & Lactobacillales & 91,34 & Enterococcaceae & 2,77 \\
& & & & & & Lactobacillaceae & 2,13 \\
& & & & & & Leuconostocaceae & 0,24 \\
Proteobacteria & 8,42 & Gammaproteobacteria & 8,42 & Enterobacteriales & 7,69 & Enterobacteriaceae & 7,69 \\
& & & & Pasteurellales & 0,66 & Pasteurellaceae & 0,66 \\
& & & & Pseudomonadales & 0,07 & Moraxellaceae & 0,07 \\
\hline
\end{tabular}


Tablo2. Peynir örneklerinin metagenomik analizi ile belirlenen tüm taksonomik üniteler.

\begin{tabular}{|c|c|c|c|c|c|c|}
\hline Filum & Sinıf & Takım & Aile & Cins & $\begin{array}{c}\% \\
\text { harita okuma }\end{array}$ & Türler \\
\hline Actinobacteria & Actinobacteria & Actinomycetales & Micrococcaceae & Kocuria & 0,01 & salcida/varians \\
\hline \multirow[t]{8}{*}{ Firmicutes } & Bacilli & Bacillales & Staphylococcaceae & Macrococcus & 0,19 & caseolyticus/carouselicus \\
\hline & & & & Staphylococcus & 0,05 & aureus/simiae \\
\hline & & Lactobacillales & Enterococcaceae & Enterococcus & 2,772 & $\begin{array}{l}\text { italicus } \\
\text { durans } \\
\text { faecium } \\
\text { hirae } \\
\text { lactis } \\
\text { mundtii } \\
\text { raffinosus } \\
\text { thailandicus } \\
\text { villorum }\end{array}$ \\
\hline & & & Lactobacillaceae & Lactobacillus & 2,12 & $\begin{array}{l}\text { brevis } \\
\text { fabifermentans } \\
\text { paraplantarum } \\
\text { pentosus } \\
\text { plantarum } \\
\text { xiangfangensis }\end{array}$ \\
\hline & & & & Pediococcus & 0,01 & pentosaceus/argentinicus \\
\hline & & & Leuconostocacceae & Leuconostoc & 0,24 & $\begin{array}{l}\text { mesenteroides } \\
\text { lactis } \\
\text { pseudomesenteroides }\end{array}$ \\
\hline & & & Streptococcaceae & Lactococcus & 85,42 & $\begin{array}{l}\text { lactis } \\
\text { raffinolactis } \\
\text { garvieae } \\
\text { taiwanensis }\end{array}$ \\
\hline & & & & Streptococcus & 0,78 & parauberis/uberis \\
\hline \multirow[t]{16}{*}{ Proteobacteria } & Gammaproteobacteria & Enterobacteriales & Enterobacteriaceae & Buttiauxella & 0,75 & $\begin{array}{l}\text { agrestis } \\
\text { ferragutiae } \\
\text { izardii } \\
\text { noackitiae } \\
\text { warmboldiae }\end{array}$ \\
\hline & & & & Citrobacter & 3,03 & $\begin{array}{l}\text { murliniae } \\
\text { gillenii } \\
\text { freundii } \\
\text { braakii }\end{array}$ \\
\hline & & & & Enterobacter & 0,4 & $\begin{array}{l}\text { asburiae } \\
\text { cloacae } \\
\text { hormaechei }\end{array}$ \\
\hline & & & & Escherichia & 1,23 & $\begin{array}{l}\text { vulneris } \\
\text { albertii } \\
\text { fergusonii }\end{array}$ \\
\hline & & & & Gibbsiella & 0,31 & quercinecans \\
\hline & & & & Hafnia & 0,1 & paralvei/alvei \\
\hline & & & & Klebsiella & 0,15 & oxytoca \\
\hline & & & & Kluyvera & 0,34 & intermedia/ascorbata \\
\hline & & & & Pantoea & 0,13 & agglomerans \\
\hline & & & & Serratia & 0,76 & marcescens \\
\hline & & & & Trabulsiella & 0,09 & guamensis \\
\hline & & & & Yersinia & 0,35 & \\
\hline & & & & Yokenella & 0,65 & regensburgei \\
\hline & & Pasteurellales & Pasteurellaceae & Pasteurella & 0,01 & \\
\hline & & Pseudomonadales & Moraxellaceae & Acinetobacter & 0,06 & johnsonii \\
\hline & & & & Enhydrobacter & 0,01 & aerosaccus \\
\hline
\end{tabular}


Tablo3. Peynir mikrobiyomunun metagenomik analizi ile belirlenen türlerin ortalama relatif \%oranları. Tabloda türün bulunduğu toplam örnek sayısı, okunan sekansın referans genoma \% homolojisi ve forward:reverse oranı ayrı sütunlarda gösterilmiştir.

\begin{tabular}{|c|c|c|c|c|c|}
\hline Cins & Tür & Pozitif örnek sayısı & ort. Relatif \% & $\%$ ID & F:R \\
\hline \multirow[t]{2}{*}{ Kocuria } & salcida & 3 & 0,005 & $>99$ & \\
\hline & varians & 2 & 0,005 & $>99$ & \\
\hline \multirow[t]{2}{*}{ Macrococcus } & caseolyticus & 5 & 0,1 & $99.17-100$ & $37.6: 62.4$ \\
\hline & carouselicus & 2 & 0,09 & $>99$ & \\
\hline \multirow{2}{*}{ Staphylococcus } & aureus & 3 & 0,04 & $>99$ & \\
\hline & simiae & 2 & 0,01 & $>99$ & \\
\hline \multirow[t]{9}{*}{ Enterococcus } & italicus & 5 & 1,8 & $99.11-100$ & $73.33: 26.67$ \\
\hline & durans & 3 & 0,67 & $>99$ & \\
\hline & faecium & 2 & 0,05 & $>99$ & \\
\hline & lactis & 2 & 0,075 & $>99$ & \\
\hline & hirae & 2 & 0,04 & $>99$ & \\
\hline & villorum & 1 & 0,047 & $>99$ & \\
\hline & mundtii & 1 & 0,039 & $>99$ & \\
\hline & thailandicus & 1 & 0,03 & $>99$ & \\
\hline & raffinosus & 1 & 0,021 & $>99$ & \\
\hline \multirow[t]{6}{*}{ Lactobacillus } & brevis & 5 & 1,1 & $100-100$ & $100: 0$ \\
\hline & fabifermentans & 3 & 0,77 & $>99$ & \\
\hline & pentosus & 2 & 0,1 & $>99$ & \\
\hline & paraplantarum & 1 & 0,07 & $>99$ & \\
\hline & xiangfangensis & 1 & 0,05 & $>99$ & \\
\hline & plantarum & 1 & 0,03 & $>99$ & \\
\hline \multirow[t]{2}{*}{ Pediococcus } & pentosaceus & 3 & 0,005 & $>99$ & \\
\hline & argentinicus & 2 & 0,005 & $>99$ & \\
\hline \multirow[t]{3}{*}{ Leuconostoc } & mesenteroides & 3 & 0,1 & $>99$ & \\
\hline & lactis & 2 & 0,08 & $>99$ & \\
\hline & pseudomesenteroides & 1 & 0,06 & $>99$ & \\
\hline \multirow[t]{4}{*}{ Lactococcus } & lactis & 5 & 84 & $99.02-100$ & $79.94: 20.06$ \\
\hline & raffinolactis & 5 & 1,35 & $99.11-100$ & $90.7: 9.3$ \\
\hline & garvieae & 5 & 0,065 & $99.14-99.14$ & $0: 100$ \\
\hline & taiwanensis & 1 & 0,005 & $>99$ & \\
\hline \multirow[t]{2}{*}{ Streptococcus } & parauberis & 5 & 0,69 & $99.1-100$ & $37.27: 62.73$ \\
\hline & uberis & 2 & 0,09 & $>99$ & \\
\hline \multirow[t]{5}{*}{ Buttiauxella } & ferragutiae & 3 & 0,25 & $>99$ & \\
\hline & agrestis & 2 & 0,17 & $>99$ & \\
\hline & izardii & 2 & 0,15 & $>99$ & \\
\hline & warmboldiae & 1 & 0,1 & $>99$ & \\
\hline & noackitiae & 1 & 0,08 & $>99$ & \\
\hline \multirow[t]{4}{*}{ Citrobacter } & freundii & 5 & 1,7 & $99.17-100$ & $43.24: 56.76$ \\
\hline & gillenii & 5 & 0,8 & $99.08-100$ & $27.06: 72.94$ \\
\hline & murliniae & 5 & 0,34 & $100-100$ & $42.34: 57.66$ \\
\hline & braakii & 1 & 0,19 & $>99$ & \\
\hline Enhydrobacter & aerosaccus & 5 & 0,01 & $100-100$ & $100: 100$ \\
\hline
\end{tabular}




\begin{tabular}{|c|c|c|c|c|c|}
\hline Cins & Tür & Pozitif örnek sayısı & ort. Relatif \% & $\%$ ID & $F: R$ \\
\hline \multirow[t]{3}{*}{ Enterobacter } & asburiae & 3 & 0,2 & $>99$ & \\
\hline & cloacae & 2 & 0,1 & $>99$ & \\
\hline & hormaechei & 1 & 0,1 & $>99$ & \\
\hline \multirow[t]{3}{*}{ Escherichia } & vulneris & 5 & 0,9 & $99.44-100$ & $48.18: 51.82$ \\
\hline & albertii & 3 & 0,18 & $>99$ & \\
\hline & fergusonii & 2 & 0,15 & $>99$ & \\
\hline Gibbsiella & quercinecans & 2 & 0,31 & $>99$ & \\
\hline \multirow[t]{2}{*}{ Hafnia } & paralvei & 5 & 0,08 & $99.58-99.58$ & $0: 100$ \\
\hline & alvei & 2 & 0,02 & $>99$ & \\
\hline Klebsiella & oxytoca & 5 & 0,15 & $100-100$ & $100: 0$ \\
\hline \multirow[t]{2}{*}{ Kluyvera } & intermedia & 5 & 0,25 & $99.58-99.58$ & $0: 100$ \\
\hline & ascorbata & 2 & 0,09 & $>99$ & \\
\hline Pantoea & agglomerans & 5 & 0,13 & $100-100$ & $100: 0$ \\
\hline Serratia & marcescens & 5 & 0,76 & $99.13-99.15$ & $0: 100$ \\
\hline Trabulsiella & guamensis & 5 & 0,09 & $100-100$ & $0: 100$ \\
\hline Yersinia & $\mathrm{sp}$ & 3 & 0,35 & $>97$ & \\
\hline Yokenella & regensburgei & 5 & 0,65 & $99.17-99.17$ & $0: 100$ \\
\hline Pasteurella & $\mathrm{sp}$ & 2 & 0,01 & $>97$ & \\
\hline Acinetobacter & johnsonii & 5 & 0,06 & $99.44-99.44$ & $100: 0$ \\
\hline Enhydrobacter & aerosaccus & 5 & 0,01 & $100-100$ & $100: 100$ \\
\hline
\end{tabular}

\section{Tartışma ve Sonuç}

Peynir mikrobiyolojik olarak aktif bir gidadır ve mikrobiyotası organoleptik, fiziko-kimyasal ve benzeri kendine has özelliklerinin oluşumunda önemli role sahiptir. Kültürden bağımsız yeni nesil sekans gibi yöntemlerin, peynirin sahip olduğu mikrobiyotanın detaylı incelenmesinde ve oluşumundaki mikrobiyal aktivitelerin araştırılmasında etkili hale geldiği düşünülmektedir.

Oscypek, Polonya'da Tatra dağları bölgesine özgü, çiğ koyun sütünden, starter kültür kullanılmadan üretilen, haşlamış-tütsülenmiş bir peynir çeşitidir. Oscypek peynirinin yapımı ve olgunlaşması aşamalarında oluşan mikrobiyotanın incelenmesi amaçlı yapılan çalışmada, hem kültürel hem de PCR-DGGE ve 16S rRNA gen amplikonlarının pyrosekans gibi kültürden bağımsız metodlar kullanılmıştır. Kültüre bağlı ve PCR-DGGE teknikleri ile peynirdeki predominant mikroorganizmalar saptanmış, sekans tekniği (454 pyrosekans) ile çok daha fazla düzeyde bakteri çeşitliliği saptanmiștır. Lactococcus, Lactobacillus, Leuconostoc, Streptococcus, Enterococcus gibi bakteri cinsleri her üç yöntemle de saptanmışken, Bifidobacteriaceae, Moraxellaceae (çoğunlukla Enhydrobacter) gibi ailelere bağlı subdominant bakteriler ve düşük düzeylerdeki bakteriler pyrosekans ile saptanabilmiştir. Bir peynir bakteri sisteminde bifidobacteria sekansının varlığı ilk kez bildirilmiştir. Bakterilerin yanısıra, yüksek oranda maya çeşitliliği saptanmıştır. Oscypek peynirinin bakteriyel çeşitliliğinde önemli olan Bifidobacteriaceae, Moraxellaceae (çoğunlukla Enhydrobacter) \%0,71 ve \%0,45 gibi düşük oranlarda saptanmıştır. Bölgesel şartlar, peynirin yapım aşamaları gibi sebeplere bağlı olarak, barsak mikrobiyotasına, üretim alanına (su, personel v.b.) ait olduğu bilinen Actinobacteria ve Proteobacteria bakterilerinin bulunması şaşırtıcı değildir. Sonuç okumalarının \%20'si gibi yüksek bir oranı sınıflandırılmamış taksonomi olarak belirtilmiştir [1] Polonya'da çĭ̆ koyun sütü ile yapılan peynirdeki (Oscypek) saptanan mikrobiyotada bulunan bakteriler bu çalışmada bulunan bakterilerle aynı olup bu çalışmada bifidobacteria bulunmamıştır

Azores bölgesinin (Portekiz) çiğ inek sütünden üretilen yöresel peyniri Pico 'nun bakteriyel çeşitliliğinin saptanması amacı ile yapılan 
bu ilk çalışmada, Pico peynirinin mikrobiyotasının belirlenmesi amaciyla, 16S rDNA' nın V3-V4 bölgelerinin etiketlenmiş amplikonlarının pyrosekans1 ve Operational Taxonomic Unit-based (OTU-based) analizleri yapılmıştır. Pyrosekans sonucunda, 4 filum (Firmicutes, Proteobacteria, Actinobacteria, Bacteriodetes) ve 54 cins belirlenmiştir. Predominant cins olarak Lactococcus (\%77) saptanmıştır. Staphylococcus \%0,5 olarak belirlenmiştir. OTU analizleri ile Lactococcus, Streptococcus, Acinetobacter, Enterococcus, Lactobacillus, Staphylococcus, Rothia, Pantoea ve sınıflandırılamamış Enterobacteriaceae ailesine bağlı bakteriler saptanmıştır [13]. Bu çalışmada ise Bacteriodetes filumu saptanmamış, diğer 3 filum Actinobacteria, Firmicutes, Proteobacteria belirlenmiştir, Lactococcus \%85.42 oranında saptanmıştır.

Sicilya'da (İtalya) üretilen el yapımı Ragusano peynirinin mikrobiyal çeşitliliğini araştırmak amacıyla yapılan çalışmada, PCR, reverse transcriptase-PCR ve $16 \mathrm{~S}$ rRNA genlerinin (rDNA) denature gradient gel elektroforezis (DGGE) yöntemleri kullanılmıştır. Klonlama ve sekans uygulamaları sonras1 rDNA amplikonlar1, Leuconostoc, Lactococcus lactis, Macrococcus caseolyticus türlerini kapsayan mezofilik laktik asit bakterilerinin (LAB) çiğ sütte baskın olduğu, laktik fermentasyon sırasında ise Streptococcus thermophilus'un baskın olduğu saptanmıştır. Diğer termofilik laktik asit bakterileri (Lactobacillus delbrueckii, Lactobacillus fermentum) peynirin olgunlaşması aşamasında oluşmaya başladıkları belirlenmiştir. Farklı çiftliklerde üretilen Ragusano peynirlerinin mikrobiyotasının, üretim şeklinin ve çevresel faktörlerin benzerliğine paralel olarak saptandığ 1 bildirilmiştir [12]. Bu çalışmada ise farklı olarak Streptococcus thermophilus saptanmamış, Streptococcus parauberis ve Streptococcus uberis saptanmıştır. Lactobacillus genusu \%2.12 oranında belirlenmiş, tür düzeyinde ise Lactobacillus brevis, Lactobacillus fabifermentans, Lactobacillus pentosus, Lactobacillus paraplantarum, Lactobacillus xiangfangensis, Lactobacillus plantarum saptanmıştır.

Kontinental tipte salamura peynir yapım aşamaları sırasında mikrobiyal değişimlerin saptanmas1 amaciyla yapılan bu araştırmada 16S rRNA amplikon sekansı kullanılmıştır. Peynirin olgunlaşma aşaması boyunca, uzun olgunlaşma gününe sahip peynirlerde, kısa süreli olgunlaşma gününe sahip peynirlere göre daha fazla mikrobiyal çeşitliliğe sahip olduğu belirlenmiştir. Pastörize sütten üretilmiş kontinental tip peynirlerle ilişkilendirilmeyen Thermus, Pseudoalteromonas, Bifidobacterium genumlarının tespit edilmesi dikkat çekici bir sonuç olarak bildirilmiştir. Klasik kültür analiz yöntemleri ve PCR tekniği tüm mikrobiyal popülasyonun saptanmasinda yetersiz kalmaktadır. High throughput next generation sequencing (NGS) yüksek düzeyde kompleks ekosistemlerde dominant ve sub-dominant mikrobiyal popülasyonların anlamlı analizlerine olanak sağlamaktadır. Analizler sonucunda $\alpha$-çeşitliliğin peynirin olgunlaşma aşamasında azaldığı saptanmıştır. Filogenetik olarak 5 filuma (Firmicutes, Proteobacteria, Bacteroidetes, Deniococcus-Thermus, Actinobacteria) ait bakte-

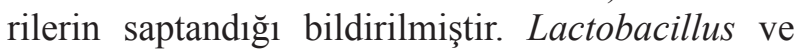
Streptococcus populasyonları hem kısa olgunlaştırma süresine sahip hem de uzun olgunlaştırma süresine ait peynir örneklerinde dominant düzeyde saptanmıştır. Acinetobacter ve Pseudomonas sadece erken olgunlaştırma süresine sahip peynirlerde, Corynebacterium ve Brevibacterium yalnızca uzun olgunlaştırma süresine sahip peynir örneklerinde sub-dominant olarak saptanmışlardır [16]. Bu çalışmada 3 filum (Firmicutes, Actinobacteria, Proteobacteria ) belirlenmiştir.

Gıda üretim alanlarındaki mikrobiyal kontaminasyon gıda kalitesi ve güvenliği açısından oldukça önemlidir. Bu araştırmada bir süt işletmesi üretim alanındaki mikrobiyota hem 16S rRNA hem de 26S rRNA bazlı high-throughput amplikon sekans (HTS) ile çalışılmıştır. Çevresel svapların mikrobiyotasının oldukça kompleks olduğu, 200'den fazla taksonomik birim içerdiği bildirilmiştir. Örneklerin \%70'inin mikrobiyotasında laktik asit bakterileri özellikle Streptococcus thermophilus baskın olarak saptanmıştır. Örneklerin \%50'sinin mikrobiyotasinda da peynirlerde bozulmaya sebep olan Pseudomonas, Acinetobacter, Psychrobacter bakterileri belirlenmiştir. En yoğun olarak saptanan mayalar ise Kluyveromyces marxanius, Yamadazyma triangularis, Trichosporon faecale, Debaryomyces hansenii olarak bildirilmiştir. Beta-çeşitlilik analizlerinin, maya ve bakteri popülasyonlarına bağ $1_{1}$ olarak çevresel ve peynir örnekleri arasındaki ay- 
rımı net olarak gösterdiği bildirilmiştir [15]. Bu çalışmada Acinetobacter saptanmış, Pseudomonas ve Psychrobacter saptanmamıştır. Moraxellaceae ailesinden Acinetobacter johnsonii ve Enhydrobacter aerosaccus tüm peynir örneklerinde bulunmuştur.

Yerel süt mikrobiyotasının, teknolojik ve çevresel parametrelerin olgunlaştırılmış peynirin mikrobiyotası üzerine etkilerini, farklı ortamlarda üretilen Gouda peynirinin yapısinda bulunan predominant mikrobiyal yapının çeşitliliğini araştırmak amaçlı bu çalışmada, analizlerde PCR-denaturing gradient gel electrophoresis (PCR-DGGE) tekniği kullanılmiştır. Pastörize sütten üretilen Gouda peynirlerindeki bakteriyel çeşitliliğin düşük düzeylerde olduğu bildirilmiștir. Çiğ sütten üretilen peynirlerdeki enterokok ve pediokok çeşitliliği, pastörize sütten üretilen peynirlerdekine göre bir miktar yüksek düzeyde saptanmıştır. Peynirdeki lezzet oluşumunda önemli yeri olan Lactobacillus plantarum yalnızca çiğ sütten üretilen peynirlerde saptanmıştır. Bir günlük olan ve çiğ sütten üretilen peynirlerde mastitis etkeni olan Streptococcus dysgalactiae saptanmıştır ve yine çiğ sütten üretilmiş peynirlerde Enterobacteriaceae genumumda yer alan Gammaproteobacteria yüksek düzeylerde bulunmuştur [5]. Bu çalışmada Lactobacillus plantarum 1 peynir örneğinde saptanmışken, Lactobacillus brevis tüm peynir örneklerinde saptanmış, Gammaproteobacteria \%8,42 oranında saptanmıştır.

Camembert peyniri gibi kompleks bir ekosisteme sahip peynirin real-time PCR (qPCR) tekniği ile maya ve küf yönünden mikrobiyotasının araştırıldığı çalışma sonucunda peynir ekosisteminde, Kluyveromyces lactis az yoğunlukta iken, Penicillium camemberti ve Geotrichum candidum'un hizlica dominant hale geldikleri saptanmıștır. Peynir ekosistemine katılan Debaryomyces hanseii' in ise Kluyveromyces lactis'in gelişimini tamamen inhibe ettiği bildirilmiştir [8].

Yeni nesil sekans sisteminin ve bununla ilișkili bioinformatik araçların kalite skorları, kullanılan filtreler ve yüksek homoloji düzeyleri, okumaların ve sonuçların \%99 üzerinde güvenilir olduğunu gösterdi. İncelenen peynir örneklerinde ortak olarak bulunan mikrobiyomun kompozisyonu sütte doğal olarak bulunan bakterilerin yansıması olarak değerlendirildi. Elde edilen bulgular geleneksel peynirin olgunlaşmasında Lactococcus lactis'in baskın olduğunu göstermektedir, ayrıca bunun yanında Lactobacillus, Enterococcus ve diğer Lactococcus türlerinin peynirin tat, koku, aroma gibi özelliklerinin oluşumunda rol aldığ1 düşünülmüştür. Muhtemelen peynirin konvansiyonel kültüründe ayırt edilemeyen Lactobacillus brevis, Lactobacillus fabifermentans, Lactobacillus pentosus, Lactobacillus paraplantarum, Lactobacillus xiangfangensis, Lactobacillus plantarum gibi diğer türlerinde geleneksel peynir üzerindeki etkilerinin incelenmesi gerektiğini göstermiştir. Sütün doğal yapısında bulunan ve peynir oluşumunda rol oynayan bakteriler yanında, genellikle patojen ve komensal bakterileri kapsayan proteobakterilerinde bulunması, peynirdeki olası kontaminasyonları ve halk sağlığ1 yönünü akla getirmektedir. Ancak gerek bu gruptaki bakterilerin relatif yoğunluğunun düşük olması ve gerekse bu bakterilerin taksonomik dağılımı, bunların kaynağının fekal kontaminasyon olduğunu düşündürmüştür. Tespit edilen proteolitik bakterilerin dağılımı ruminant fekal mikrobiyomu ile uyum göstermektedir. Kırsal kesimdeki süt sağım koşulları, koyun sağımındaki bilinen kontaminasyon olasılığı gözönüne alındığında saptanan proteobakterilerin özellikle enterobakterilerin varl1ğının normal olduğunu düşündürmüştür.

\section{Teșekkür}

Bu çalışmada teknik destek sağlayan Prof.Dr. K. Serdar DİKER'e teşekkür ederiz.

\section{Kaynaklar}

1. Alegria A, Szczesny P, Mayo B, Bardowski J, Kowalczyk M, (2012). Biodiversity in Traditional Polish Cheese Oscypek Determined by Culture-dependent and -independent Approaches. Appl Environ Microbiol. 78(6), 1890-1898.

2.Anonim, Dünyada ve Türkiye'de Peynir Üretimi. Eylül 2013. http://ankaratb.org.tr/lib upload/25202013. Erișim tarihi:08.07.2017.

3. Buermans HPJ, Dunnen JT, (2014). Next generation sequencing technology: Advances and applications. Molecular Basis of Diseases, vol.1842, 10, 1932-1941.

4. Dijk EL, Auger H, Jaszczyszyn Y, Thermes C, (2014). Ten years of next-generation sequencing technology. Trends In Genetics, vol.30, 9, 418-426.

5. Hoorde KV, Heyndrickx M, Vandamme P, Huys G, (2010). Influence of Pasteurization, Brining Conditions and Production Environment on the Microbiota of Artisan Gouda-type Cheese. Food Microbiol. 27, 425-433. 
6. Jonnala BRY, McSweeney PLH, Sheehan JJ, Cotter PD, (2018). Sequencing of the Cheese Microbiome and Its Relevance to Industry, Review. Front Microbiol. 9, 1-12.

7. Lessard M-H, Belanger G, Gelais St, Labrie S, (2012). The Composition of Camembert Cheese Ripening Cultures Modulates Both Mycelial Growth and Appearance. Appl Environ Microbiol.78(6), 1813-1819.

8. Montel MC, Buchin S, Mallet A, Paus CD, Vuitton DA, Desmasures N, Berthier F, (2014). Traditional Cheeses: Rich and Diverse Microbiota With Associated Benefits. Int J Food Microbiol. 177, 136-154.

9. Ndoye B, Rasolofo EA, Lapointe G, Roy D, (2011). A Review of the Molecular Approaches to Investigate the Diversity and Activity of Cheese Microbiota. Dairy Sci\& Technol. 91, 495-524.

10. Quigley L, Sullivan OO, Beresford TP, Ross RP, Fitzgerald GF, Cotter PD, (2011). Molecular Approaches to Analysing the Microbial Composition of Raw Milk and Raw Milk Cheese. Int J Food Microbiol. 150, 81-94.

11. Randazzo CL, Torriani S, . Akkermans ADL, Vos WMd, Vaughan EE, (2002). Diversity, Dynamics and Activity of Bacterial Communities during Production of an Artisanal Scilian Cheese as Evaluated by $16 \mathrm{~S}$ rRNA Analysis. Appl Environ Microbiol. 68(4), 1882-1892.
12. Riquelme C, Camara S, de Lurnes N.E Dapkevicius M, Vinuesa P, Costa G da Silva C, Malcata FXA, Rego O, (2015). Characterization of bacterial biodiversity in Pico cheese (an artisanal Azorean food). Int J Food Microbiol. 192(1), 86-94.

13. Sanchez SD, Hanning I, Pendleton S, Souza DD, (2013). Next-generation sequencing:The future of moecular genetics in poultry production and food safety. Poult Sci. 92, 562-572.

14. Stellato G, Filippis FDE, Storia ALa, Ercolini D, (2015). Coexistence of Lactic Acid Bacteria and Potential Spoilage Microbiota in a Dairy Processing Environment. Appl Environ Microbiol. 81(22), 7893-7904.

15. Sullivan DJO, Cotter PD, Sullivan OO, Giblin L, McSweeney PLH, Sheehan JJ, (2015). Temporal and spatial differences in microbial composition during the manufacture of a Continental-type cheese. Appl Environ Microbiol. 81(7), 2525-2533.

16. Tan S, Ertürk YE, (2002). Peynir. TEAE Bakış Derg. 1(11), 1-4.

17. Türk G1da Kodeksi. 01.01.2016 yürürlük tarihli, Resmi Gazete, 08.02.2015. 